INTERNATIONAL JOURNAL OF MULTIDISCIPLINARY RESEARCH AND ANALYSIS

ISSN(print): 2643-9840, ISSN(online): 2643-9875

Volume 03 Issue 12 December 2020

DOI: 10.47191/ijmra/v3-i12-08, Impact Factor: 5.522

Page No.- 318-320

\title{
Organization of Management in the System of Preschool Education on the Basis of Pedagogical Partnership
}

\author{
Nargiza Fathullaevna Abdunazarova ${ }^{1}$, Makhzuna Tursunovna Khamdamova ${ }^{2}$, \\ Zilola Uralovna Kurbonova ${ }^{3}$ \\ ${ }^{1}$ Candidate of Pedagogical Sciences, Associate Professor, Institute of retraining and advanced training of managers and \\ specialists of preschool educational institutions, Tashkent, Uzbekistan \\ ${ }^{2}$ Independent researcher, Institute of retraining and advanced training of managers and specialists of preschool educational \\ institutions, Tashkent, Uzbekistan \\ ${ }^{3}$ Independent researcher, Institute of retraining and advanced training of managers and specialists of preschool educational \\ institutions, Tashkent, Uzbekistan
}

ABSTRACT: The article is devoted to the analysis of the concept of "management" and the modern management organization of a preschool educational organization. The authors report that for an effective and rational leadership of a modern preschool educational institution, the leader must master the basics of management, modern effective partnership strategies, teamwork technologies based on a positive constructive approach and leadership functions of the leader.

KEYWORDS: management, pedagogical partnership, preschool education.

\section{INTRODUCTION}

The requirements for modern education and social order pose educational organizations the need to work in development mode. The main mechanism of activity of a developing educational organization is the search and development of innovations that contribute to qualitative changes. This also applies to the system of preschool education. For the successful implementation of the modernization process, any education system needs modern methods of managing the collective of participants in educational relations. The system of preschool education has a number of specific features that are naturally reflected in existing management models.

\section{METHODOLOGY}

There are many definitions of the concept of "management." V.I. Dahl, "management" is interpreted as an opportunity "to give a move, a direction, to force one to go the right, right way, to dispose, manage, do something good, work well, okay" [9].

Many scientists who dealt with the problem of managing educational systems interpreted it as activities to streamline and coordinate relations in the process of joint work (V.I. Zagvyazinsky, V.Yu. Krachevsky, V.A.Slastenin, M.M. Potashnik and others) . For many years, management was defined as a continuous and focused process of influencing a team of people to organize and coordinate their activities in the production process, in order to achieve the best results at the lowest cost [2, p. 96].

\section{RESULTS AND DISCUSSION}

Note that in the Big Explanatory Dictionary, impact is an action, an influence exerted by someone, something on someone, something. Influence is the process and result of changes by one subject of the behavior, psyche of another subject. The process of mutual influence of people on each other in the process of communication; the conjugation of mutual influence systems is defined in psychology as interaction.

The sixties and eighties of the twentieth century became a period of deep interest in the category of "interaction" in pedagogical theory and practice. In these years, concepts such as "interconnection", "contact", "combination", etc. are used to denote interaction processes. 


\section{Organization of Management in the System of Preschool Education on the Basis of Pedagogical Partnership}

The issues of pedagogical interaction are investigated in the works of A.F. Amenda, I.V. Grebennikova, V.D. Semenova and others $[1 ; 3 ; 6]$. The publications of Sh.A. are devoted to the psychological and pedagogical understanding of pedagogical interaction in the educational process. Amonashvili, L.V. Bayborodova, A.S. Belkina, V.A. Bukhvalova, G.V. Gatalsky, A.A. Gin, T.G. Grigorieva, I.A. Winter, E.V. Korotaeva, P.I. Pidkasisty, I.I. Rydanova.

According to E.V. Korotayeva, the modern idea of pedagogical interaction is based on understanding it as a deterministic educational situation of the special connection of subjects and objects of education, based on event-informative, organizationalactivity and emotional-empathy unity and leading to quantitative and / or qualitative changes in the organization of the pedagogical process [ 5, p. 256]. Changes as a result of pedagogical interactions can be both developing and destructive.

Thus, the types of pedagogical interactions are determined: constructive and destructive.

The main characteristics of the interaction manifest themselves in different ways depending on the conditions and situations in which the participants in the pedagogical process interact, which allows us to talk about many types of interaction. Scientists (L.V. Baiborodova, A.S. Belkin, H.Y. Liimets, V.A. Liaudis, A.K. Markova, Yu.M. Orlov and others) have proposed various grounds for their classification.

We agree with the opinion of E.V. Korotaeva, that the classification basis proposed by A. S. Belkin on the correlation of rights and obligations perfectly reflects the modern educational paradigm: humanistically oriented pedagogy, personality-developing education [5, p. 256].

The modern educational paradigm leads to the realization that the implementation of the strategic goals of modernization of Russian education cannot be achieved without a multifunctional system of public preschool education focused on satisfying the needs of parents, who are the main customers of educational services.

In the practice of interaction between participants in educational relations, it is necessary to exchange information and the activity itself, that is, it becomes partners and jointly realize their specific capabilities in raising children. In this regard, partnerships between parents and teachers contribute to positive results in the education of preschool children [4, p. 74].

The concept of "partnership" entered into pedagogy from the social, labor and economic spheres, treating it as a mechanism of relations between government bodies, representatives of workers and employers, as a specific type of social relations, as a way of interaction between different social groups.

Partnership is a special type of joint activity between parents and an educational institution, characterized by trust, common goals and values, voluntariness and long-term relations, as well as recognition of the mutual responsibility of the parties for the result of the development of all subjects of education [8, p. 24].

The partnership of teachers and parents implies the opening of a preschool educational institution to society, which in turn implies changes in the field of management, the organization of the educational process. At the same time, it is important to take into account the multidimensionality, internal qualities and features of the history of the development of the system of preschool education in the country.

One of the management features at the present stage of modernization of the preschool education system is the rejection of the traditional forms of organizational structure, the restructuring of structures in accordance with the requirements of high mobility for solving issues in a unified education system, kindergarten - school. An example of such an educational structure is a large educational complex that can provide residents of the micro district with the whole range of services that consumers need. However, the operating conditions, the management system and the coordination of pedagogical efforts in the new conditions, including the legal support of the work of these structures, have not been studied enough.

\section{CONCLUSION}

Summing up, we note that the organization of the management system of a preschool educational organization as a structural unit of the educational complex involves the reorganization of the personnel management system in a preschool educational organization, depending on the needs of society; improving the work of the methodological service; the creation of a psychological support service for teachers involved in innovative activities; improving the regulatory framework (local acts, the main educational program, the organization of additional education, etc.), which regulates the continuity of the educational activities of the preschool organization and the school; creation of conditions for the creative search for new methods of working with children, providing their individual development path.

Thus, for effective and rational management of a modern preschool educational organization, the leader must master the basics of management, modern effective partnership strategies, teamwork technologies based on a positive constructive approach and leadership functions of the leader. 


\section{Organization of Management in the System of Preschool Education on the Basis of Pedagogical Partnership}

\section{REFERENCES}

1) Amend A.F. The interaction of schools, families and the public in the economic education of children (method. Recommendations), scientific. Editor A.N. Zvyagin. - Chelyabinsk: ChSPI, 1987.

2) White K.Yu. Methodical work in a preschool educational institution: analysis, planning, forms and methods / K.Yu. White. - M.: SC Sphere, 2005. - 96 p.

3) Grebennikov I.V. Strengthening the relationship of public and family education of children and adolescents // Soviet Pedagogy. - 1985. - No. 1. - P. 80-86.

4) Dubrova V.P. Theoretical and methodological aspects of the interaction of kindergarten and family: Textbook. - Minsk, 1997. $-74 \mathrm{p}$.

5) Korotaeva EV Pedagogical interactions and technologies. Ministry of Education and Science. Ural state. ped University // Monographic Studies: Pedagogy. - M.: Academia, 2007. - 256 p.

6) Semenov V.D. The interaction of the school and the social environment. - M., 1986.

7) Korotaeva E.V. Pedagogical interactions and technologies. Ministry of Education and Science. Ural state. ped University // Monographic Studies: Pedagogy. - M.: Academia, 2007. - 256 p.

8) Thesaurus of "New values of education". Anthropological, activity and cultural approaches. - 2005. - No. 5. - P. 24.

9) Explanatory dictionary of living Great Russian language / V.I. Dahl. - The electron. text data. - M .: IDDK GROUP, 2004. 